\title{
Os caminhos da cavalaria
}

\author{
Luís Otávio da Costa Linhares ${ }^{1}$
}

\section{Introdução}

Cavalaria. Esse termo, se consultado em um manual ou dicionário especializado, poderá constar em até dez significações diferentes.

É possível se referir à cavalaria como um grupo de cavaleiros ou soldados à cavalo, armados para a luta. No período romano da Monarquia, ou Realeza, a centuriae equitum era um grupo de soldados que combatiam à cavalo. Neste período, a cavalaria era apenas isso. Já no sentido abstrato, cavalaria é uma dignidade ou ordem, posição e qualidade de cavaleiro. É o que na Idade Média poderia ser chamado de "espírito cavalheiresco". De maneira técnica, vassalagem por serviço cavalheiresco. "A cavalaria é o juramento de vassalagem pelo qual o vassalo fica obrigado a prestar qualquer serviço nobre ou militar ao senhor". 2 Finalmente, emprega-se o termo cavalaria para designar todo um sistema social, político e militar da Idade Média.

Essas quatro definições podem explicitar o que foi a cavalaria, em um sentido bem amplo.

Através delas tentarei, neste trabalho, explicitar o que foi a cavalaria. Tentarei mostrar como aquela noção de soldado montado para os romanos, chegou até o final da Idade Média como a de um gentil-homem, atribuído de qualidades que nenhum outro indivíduo possuía.

\section{O cavaleiro em Roma}

Para os romanos, no período da Realeza, ainda não se tinha pensado no cavaleiro como uma força independente de guerra. Eram apenas soldados de infantaria que montavam cavalos, conseguindo assim maior mobilidade para a defesa e para o ataque.

Esses soldados dividiam-se em centúrias. ${ }^{3}$ Para fazer parte dessas centúrias, havia a necessidade do indivíduo ser considerado antes de tudo cidadão. ${ }^{4}$ Os mais ricos formavam a centuriae equitum (centúria de cavaleiros), que somava um total de mil e oitocentos homens. ${ }^{5}$

\footnotetext{
1 Graduação - História/UFPR

${ }^{2}$ POSTAGE, Edgar. A Cavalaria Medieval. Pg. 12

${ }^{3}$ Grupos de cem combatentes. Por vezes pouco mais ou pouco menos. (GIORDANI, pg. 113)

${ }^{4}$ Para os romanos, ser cidadão era ter posses, principalmente terras. (GIORDANI, pg. 113)

${ }^{5}$ GIORDANI, Mario C.. História de Roma. Pg. 112
} 
Na República, o Exército sofreu mudanças significativas: as primeiras foram feitas por Camilo (Ditador romano do século III a.C.). ${ }^{6}$ O Exército romano era composto por legiões (mais ou menos seis mil homens), articuladas em manípulos (cada manípulo era composto de duas centúrias) e centúrias. Cada legião seria acrescida de um corpo de cavalaria. Agora, a cavalaria, ainda composta de homens de maiores posses, ficaria dividida em dez esquadrões (turmae) de três decúrias (cada decúria corresponde a dez homens), totalizando trezentos homens.

A mudança de Camilo, pode-se dizer, obteve resultados apenas no campo militar. A grande inovação nasceria com Mario (eleito cônsul no ano de 107 a.C. Seria reeleito mais cinco vezes para o mesmo cargo até o ano de 100 a.C.), que acabaria por reformular todo o Exército romano, ocasionando grandes mudanças políticas futuras como conseqüência.

Roma estava em uma época de profunda expansão. Necessitava de terras para a população, que aumentava. As Leis Frumentárias ${ }^{7}$ dos irmãos Graco, só fizeram com que esta expansão se tornasse mais efetiva (era preciso mais espaço para plantar trigo, para que essas leis funcionassem). Porém, para conseguir mais territórios seria necessário derrotar os povos que os ocupavam. Há nesse período um grande desenvolvimento militar, "encabeçado" por Mario.

A primeira reforma foi recrutar não-cidadãos, ou seja, homens que não possuíam posses. Assim, esses novos combatentes poderiam ficar no campo de combate quanto tempo fosse necessário, enquanto os possuidores de terras e os comerciantes não podiam fazê-lo. Aqueles por causa da colheita e estes pelos negócios. Contudo, ambos para lidar com a política.

A cavalaria legionária foi dando lugar à cavalaria formada por tropas auxiliares, de númidas, trácios, hispanos ou germanos. Tais povos possuíam uma técnica mais aprimorada no manejo do cavalo e, depois de derrotados, eram imediatamente incorporados ao Exército.

Muda-se o aparato militar. A legião passa a ser uma unidade autônoma de combate. Agora existem unidades de apoio, pois os soldados não mais regressam. Táticas de guerra foram renovadas e outras mais, inventadas.

Enfim, todas as mudanças de Mario teriam como conseqüência a profissionalização do Exército. Pessoas pobres adeririam às legiões para tentar ganhar dinheiro e prestígio. Assim, a figura central seria o chefe do Exército, e não mais o Estado. A lealdade do soldado ficaria restrita aos generais, que em algumas ocasiões seriam também os comandantes do Estado. Tais reformas militares tiveram "como consequiência o aparecimento do soldado profissional,

\footnotetext{
${ }^{6}$ Como o tema que estou abordanco é a cavalaria, durante este trabalho apresentarei apenas as mudanças referentes à mesma.

${ }^{7}$ Venda de trigo pelo Estado a baixos preços, por vezes até distribuição gratuita. (GIORDANI, pg. 52)
} 
que fazia do serviço militar um meio de vida, mais apegado à pessoa dos seus generais do que à Constituição republicana". ${ }^{8}$ Isso reflete o que será o período do Império, onde o Exército é quem vai eleger e "deseleger" os imperadores.

Um século antes dessas reformas, a sociedade romana estava, basicamente, estruturada em três classes: a nobreza senatorial, os cavaleiros e a população rural.

Ora, se um século antes das reformas de Mario, a cavalaria já se organizava como uma ordem - Ordem Eqüestre $-^{9}$ o que impediria, após a profissionalização do Exército, essa mesma cavalaria de começar a ascender ao poder?

A nobreza possuía a preocupação de impedir o acesso ao poder dos que não integravam a nobilitas. ${ }^{10}$ Afastaram então os cavaleiros dos comandos e das magistraturas, posições às quais tinham acesso desde o século III a.C. (acesso este cedido pelos censores, para ampliar os quadros da cavalaria). "Afastados, em tempo de guerra, do comando, e, em tempo de paz, das magistraturas, os cavaleiros procuraram um outro emprego para a sua fortuna". ${ }^{11}$

Desta maneira, os cavaleiros seguem, com os bolsos cheios de dinheiro, para outra empreitada: as empresas públicas. Unem-se, então, aos arrendatários dos serviços públicos, e formam assim uma nova aristocracia. Este serviço foi facilitado pelo simples fato de a nobreza senatorial não poder exercer o grande comércio. Os cavaleiros ficam assim conhecidos como "homens de negócios". ${ }^{2}$ Simplesmente como exemplo, eles tornaram-se indivíduos tão influentes em Roma, que conseguiram chegar ao poder máximo, como foi o caso de Julio César.

Assim, o espaço que compreende alguns anos antes do início do calendário cristão foi uma época de transição, em que o poder estava nas mãos de duas classes privilegiadas, o senado e os cavaleiros, e de onde surgia um novo sistema de monarquia, conhecida em um âmbito geral como Império.

No Império, a hierarquia sofreu alterações. O imperador era o comandante supremo. Foram criados corpos de milícias destinados para fins especiais, os mais conhecidos foram as cohors praetoria, ou seja, guarda

\footnotetext{
${ }^{8}$ GIORDANI, Mario C.. História de Roma. Pg. 53

${ }^{9}$ Legalmente só existiu uma ordem eqüestre, quando o Império estava sob o comando de Otavio Augusto.

10 "Interesses comuns e uniões matrimoniais haviam aproximado e unido facções outrora rivais, e dessa união surgira uma nova aristocracia patrício-plebéia que passou a constituir a nobilitas. Era uma verdadeira casta, exclusivista e dominadora, que se apoderou dos altos cargos e do senado." (GIORDANI, pg.188)

11 GLOTZ. Histoire Romaine, t. II, pg. 33. IN: GIORDANI, Mario C.. História de Roma. Pg. 207

${ }^{12}$ ROSTOVTZEFF, M. História de Roma. Pg. 149
} 
pretoriana, composta de infantes e cavaleiros. Ela "desempenhou, muitas vezes, o papel decisivo na escolha do imperador". 13

Otavio Augusto cria, oficialmente, a Ordem Eqüestre.

\begin{abstract}
“A Segunda classe do Império, a dos cavaleiros, não só acatava a posição de Augusto como o apoiava de todas as maneiras possíveis e mostrou-se sempre muito dedicada a ele. Essa poderosa classe de homens de negócios, que saíra ainda mais forte das guerras civis e muito maior, a despeito das numerosas vítimas colhidas pela guerra, não podia deixar de estar satisfeita com o tratamento que recebera de Augusto. O passado desonroso de muitos desses homens foi esquecido, a classe oficialmente declarada como a Segunda do estado e ramo hereditário da aristocracia. Os cavaleiros receberam direitos definidos na vida pública (...). Houve aiguns recuos: a esfera da sua atividade foi gradualmente restringida e, em particular, perderam inteiramente o antigo controle absoluto das transaçôes relacionadas com a coleta de impostos (...). No conjunto, porém, essa classe ganhou muito mais do que perdeu.,"14
\end{abstract}

A classe dos cavaleiros enriqueceu, famílias novas ingressaram nela. $\mathrm{O}$ título de equites já não era mais o mesmo daquelas dezoito centúrias de prestadores de serviço à cavalaria. Qualquer indivíduo que dispusesse do título de cidadão e cujas propriedades tivessem um valor superior a quatrocentos mil sestércios, poderia fazer parte da Ordem Eqüestre. Note-se que para o cidadão ser considerado um homem rico, deveria possuir propriedades com um valor superior a vinte milhões de sestércios.

Após Augusto, sobe ao poder a dinastia Julio-Claudia, que durou de 14 à 68 d.C.. O sucessor de Augusto foi Tibério, um "cinqüentão" que optou pela paz às glórias militares. Calígula, o próximo, filho de Germânico, sobrinho de Tibério. Após uma enfermidade passou a sofrer de insanidade, tomando atitudes desatinadas: tentou introduzir em Roma um despotismo teocrático à moda oriental, considerando-se um deus vivo. Foi assassinado por um cavaleiro da Guarda Pretoriana. Seu tio Claudio acabou assumindo o poder por vontade dos pretorianos, morreu envenenado por sua mulher Agripina. O último dessa dinastia foi Nero. Perseguiu os cristãos de Roma, sob o pretexto de haverem incendiado a cidade. Foi um imperador fraco, assim como todos os de sua dinastia, que acabaram vivendo à sombra de Otavio Augusto.

No ano que sucedeu a morte de Nero, Roma assistiu a ascensão de três imperadores: Galba, Vitélio e Otão. Estes foram imperadores que pouco fizeram e que pouco fariam pelo Império se conseguissem ter se mantido no poder. "Por isso, o aparecimento de uma nova dinastia no trono, por mais que devesse ao acaso a sua ascensão, não provocou nenhum protesto da sociedade romana". 15

\footnotetext{
${ }^{13}$ GIORDANI, Mario C.. História de Roma. Pg. 117

${ }^{14}$ ROSTOVTZEFF, M. . História de Roma. Pg. 176-177

${ }^{15}$ Idem, Ibidem. Pg. 206 
Após esse difícil ano, o Império assiste a ascensão de Flávio Vespasiano, que inaugura uma nova dinastia, a dinastia dos Flávios (69-96 d.C.), que será seguida pela dos Antoninos (96-192 d.C.). "Com os Flávios inicia-se um longo período de prosperidade e estabilidade que, continuado sob os Antoninos, assinala a Idade de Ouro do Império romano e dura bem mais de um século (69-192)". ${ }^{16}$ A partir do imperador Trajano (98-117 d.C.), Roma não mais tomara a ofensiva contra os povos bárbaros. ${ }^{17}$ Tal atitude acabou por estimular, por um lado, "talvez, os instintos belicosos e a cobiça dos bárbaros" ", e por outro, a desestruturação da sua "máquina militar".

O Exército não mais se desenvolveu, apenas assimilou algumas poucas armas militares dos povos com os quais mantinha contato. Isso deve-se a um conjunto de fatores que, após a dinastia dos Severos, levara a crise do século III. "Crise de fato estrutural: econômica, social, política, religiosa, cultural e militar". 19

O Império romano durante os séculos III, IV e V, acaba caindo definitivamente nas mãos do Exército. Os soldados aclamam seus generais como imperadores, e não ficando satisfeitos os depõem do poder, através de assassinatos, freqüentes nesta época.

"Põem-se e depõem-se imperadores por dinheiro ou por razões de amor próprio. As legiões chegam, por vezes, a apoiar um personagem militarmente incapaz quando este é rico. Mais tarde, cansam-se dele e acabam por o matar. Matam por capricho, matam por prazer..." ${ }^{20}$ Mesmo os imperadores Ilírios (268-311 d.C.), ao tentar pacificar o Império reordenando-o, baseiam seu poder na lealdade de seus soldados.

Porém, o Império ainda assiste a subida de dois imperadores que conseguem restabelecer uma certa organização política: Diocleciano e Constantino. Eles farão algumas reformas significativas do cunho militar. Em primeiro lugar, a divisão do Exército em duas unidades militares: uma para cuidar das fronteiras e outra para a parte interna do Império, aumentando o efetivo para seiscentos mil homens; em segundo, a dissolução das antigas formações militares, trocando-as por unidades menores e mais ágeis, que contaram com um número maior de cavaleiros. Por terceiro, as fortificações fronteiriças foram reforçadas; em quarto está a adoção de medidas logísticas; e por fim, a hereditariedade das funções militares.

Essas mudanças obtiveram um resultado bom, porém, modesto. O Império não tinha condições de sustentar um número elevado de soldados por

\footnotetext{
${ }^{16}$ GIORDANI, Mario C.. História de Roma. Pg.66

${ }^{17}$ Idem, Ibidem

${ }^{18}$ Idem, Ibidem. Pg. 71

${ }^{19}$ FILHO, Cyro Rezende. Guerra e Guerreiros na Idade Média. Pg. 10

${ }^{20}$ LOT, Ferdinand. O fim do mundo antigo e o princípio da Idade Média. Pg. 23 
muito tempo, e esses mesmos soldado não possuíam o mesmo profissionalismo de tempos anteriores. "Caracteriza-se esta período por um processo de decadência urbana, fruto de uma longa deteriorização das estruturas econômicas do Império, que se reflete em um êxodo urbano, e com uma ruralização geral e progressiva da sociedade. Em uma situação como esta, manter e treinar um grande exército profissional torna-se uma tarefa por demais pesada para os recursos do Estado." 21

Durante o século IV, o efetivo militar tinha duas procedências: de tribos menos romanizadas do Império e de tribos germânicas que se localizavam fora do território imperial. Ocorre, portanto, um movimento de quase total germanização do Exército romano.

As melhores tropas, mais adequadas ao serviço militar, ficavam aquarteladas próximas à capital do Império. Esses destacamentos, chamados comitatensis, compunham uma força militar pronta para marchar para os locais de perigo, a qualquer momento. Sua evolução se fizera sobre a base da Guarda Pretoriana e funcionava também como uma guarda pessoal. Continuavam a ser cavalaria, porém, eram vistos como uma espécie de "tropa de elite".

Todo esse contingente, ao atingir vinte e cinco anos de serviço militar, recebia um lote de terra como pagamento pelos serviços prestados, sempre nas regiões de fronteira. Isso fazia com que houvesse sempre uma espécie de força auxiliar, chamada por Cyro Rezende de "soldados-colonos". 22 O Império vai perdendo, assim, sua identidade, e vai se desagregando nas mãos de tribos bárbaras. Foi a ausência de combatentes romanos "que fez com que só os germânicos pudessem cumprir sua função primordial, não só dentro do Exército romano, mas também no âmbito da administração imperial: o de fornecer quadros que, se por um lado, suplementavam uma carência efetiva do Império, por outro, contribuíram para uma alteração básica em suas características fundamentais." ${ }^{23}$

O Império romano vê seu fim aproximar-se e, talvez numa última tentativa de salvar esse grandioso, porém, decrépito Império, o imperador Teodósio (383-395 d.C.) reparte-o em dois: uma metade, a ocidental, para Honório, e a outra metade, a oriental, para Arcádio, ambos seus filhos. Essa divisão adquire um caráter definitivo. Cada uma das metades seguirá seu caminho: a ocidental verá seu fim em menos de um século, a oriental sobreviverá por mais mil anos.

\footnotetext{
${ }^{21}$ FILHO, Cyro Rezende. Guerra e Guerreiros na Idade Média. Pg. 13

${ }^{22}$ FILHO, Cyro Rezende, Guerra e Guerreiros na Idade Média. Pg. 15

${ }^{23}$ Idem, lbidem. Pg. 16
} 


\section{O bárbaro ${ }^{24}$}

Durante mais ou menos quatro séculos, desde os primeiros contatos com os romanos no século I a.C. ${ }^{25}$, os bárbaros, principalmente os germanos, cresceram em importância dentro do Império. Nesse tempo, se instalaram ao longo das fronteiras. Algumas tribos tentaram adentrar em território romano por vontade própria, outras entraram empurradas por outras tribos bárbaras. Entretanto, quase sempre ocasionando atritos. Algum tempo depois, entretanto, estas tribos estariam sendo recrutadas para defender o Império. "Acolhidas, de início, como inimigas, acabam admitidas em determinadas áreas, onde passam na qualidade de federados, a defender as fronteiras imperiais contra novas invasões bárbaras.",26

A política romana para com esses bárbaros ficou conhecida como Regime de Hospitalidade ${ }^{27}$, onde esses povos recebiam terras e escravos para cultivá-la. Era a maneira que os romanos tinham para fazer com que os bárbaros os defendessem. Assim, os bárbaros crescem dentro do Exército, a ponto de se confundirem com ele. O povo romano não mais aceitou servir o Exército, quase todo composto por esses povos, nem servir sob as suas ordens. O Exército cai em mãos bárbaras, atingiririam os mais altos postos de comando, até finalmente ter todo o Império, ou o que ele foi, sob sua tutela.

Aos poucos, a sociedade romana foi-se militarizando, pois, quanto mais o germano, que se identifica muito bem como soldado, foi ascendendo ao poder, ela foi consequentemente adquirindo suas características. Não que a população deve-se estar sempre armada, mas devia sustentar o Exército. O que acontece, é que ao invés do soldado ser valorizado, ele acaba se distanciando, pois há uma aversão aos bárbaros. "Deste modo, assistimos, no decorrer dos séculos IV e V, paralelamente à progressiva militarização da sociedade romana, o distanciamento cada vez maior entre esta sociedade e o seu Exército, que além de drenar os recursos econômicos cada vez mais escassos, era composto e comandado por bárbaros." 28

Mas que sociedade é esta, que se afasta dos bárbaros? A alta sociedade, os grandes proprietários, os cristãos e todos aqueles que têm os olhos voltados para a tradição romana. Porém, ao mesmo tempo, necessita desses dos quais quer se afastar, para afastar aqueles com quem quer menos contato ainda. No entanto, esta necessidade é apenas da minoria do população

\footnotetext{
24 "Os gregos, depois os romanos, designavam pelo nome de bárbaros todos os povos declaradamente estrangeiros, rebeldes à sua civilização, seu modo de vida, suas estruturas econômicas e sociais, sua cultura, e mesmo à língua." (HEERS, Jacques. História Medieval. Pg. 14)

${ }^{25}$ FILHO, Cyro Rezende. Guerra e Guerreiros na Idade Média. Pg. 16

${ }^{26}$ Idem, Ibidem. Pg. 20

${ }^{27}$ Idem, Ibidem, Pg. 20

${ }^{28}$ FILHO, Cyro Rezende. Guerra e Guerreiros na Idade Média. Pg. 24
} 
romana. A população em geral aceitou muito bem a entrada desses povos, como coloca Le Goff: "A estrutura social do Império romano, em que as camadas populares eram cada vez mais esmagadas por uma minoria de ricos e poderosos, explica o êxito das invasões bárbaras." 29

A entrada do que é chamada Idade Média, é feita com uma "fusão entre bárbaros e romanos. ${ }^{, 30} \mathrm{~A}$ única saída para os romanos acabou sendo a de ficar ao lado desses bárbaros, fazendo com que algo ficasse como legado. A estrutura física morreu, mas não a religião, os títulos, o senado, enfim, a cultura.

\section{O cavaleiro medieval e o espírito cavalheiresco}

Aquele cavaleiro romano já citado, irá, durante os séculos posteriores à queda do Império do ocidente, entrar em um estado de mutação, sob a influência dos bárbaros e posteriormente da Igreja.

A provável origem deste cavaleiro medieval é persa: "O cavaleiro pesado sassânida, de meados do século III, inteiramente coberto, junto com a sua montaria, por proteções de metal. ${ }^{, 31}$ Este modelo de cavaleiro foi adotado pelos romanos por volta do século IV como tropa de elite (comitatensis).

As sociedades bárbaras medievais eram sociedades voltadas para a guerra. Os seus valores primordiais são os do gucrrciro. Sua organização social é ligada ao Exército e dependente dele. Todos os seus homens livres ${ }^{32}$ são, a princípio, guerreiros. A partir daí, é fácil entender que se há um confronto com um Exército que detém melhores armas e táticas de guerra, elas serão assimiladas. E é a partir desta evolução do cavaleiro persa, que nascerá o cavaleiro medieval.

Somente no século VII haverá novamente um poder único, nas mãos de um único povo. Uma aristocracia regional, a Carolíngia, vai fundar uma dinastia real em 751 d.C., e instalar um Império em 800 d.C. Tal Império teria quase toda a extensão do Império romano ocidental. Este novo Império, Império franco lançaria os fundamentos "do que seria a caracterização primária do ocidente...: o feudalismo." ${ }^{, 33}$ Dois seriam esses fundamentos: o cavaleiro couraçado e a vassalagem de benefício. Ambos ligados e mutuamente explicativos.

Os francos, em contato com outros povos, acabaram assimilando a cavalaria, apesar de serem povos mais infantes que cavaleiros. Esse processo

\footnotetext{
${ }^{29}$ LE GOFF, Jacques. A Civilização do Ocidente Medieval. VI I, pg. 36

${ }^{30}$ Idem, Ibidem. Pg. 37

${ }^{31}$ FILHO, Cyro Rezende. Guerra e Guerreiros na Idade Média. Pg. 41

${ }^{32}$ Idem, Ibidem. Pg. 28

${ }^{33}$ FILHO, Cyro Rezende. Guerra e Guerreiros na Idade Média. Pg.40 
atinge seu apogeu no século VIII com o imperador Carlos Magno (771-814 d.C.). O cavaleiro era o guerreiro mais eficiente até então e, "tendeu a se tornar a forma padrão de combatente, acarretando um profundo impacto nas estruturas sociais, de uma sociedade altamente militarizada e hierarquizada." ${ }^{34}$

Mas o que era esse cavaleiro couraçado? Porque possuía tamanha eficácia?

O cavaleiro couraçado, diferente do romano, (que cobria apenas o tronco com a armadura), usava um escudo e uma espada curta, ambos de bronze ou de ferro. Possuía o corpo protegido dos cotovelos aos joelhos por uma túnica, com um capuz que cobria a nuca e o queixo, feitos ambos de pequenos anéis ou discos de ferro entrelaçados; ou por uma túnica de couro coberta por placas de metal. Tinha um elmo cônico e um escudo triangular, ambos de metal. Utilizava uma espada longa (90 centímetros) de metal e uma lança (2 metros e 50 centímetros) de madeira, como armas de ataque. Basicamente, tal cavaleiro era colocado como tropa de choque sob as linhas inimigas. Montava cavalos que também eram armados com armaduras de couro recobertas com placas de metal. Tornavam-se, assim, cavalo e cavaleiro, quase invulneráveis às armas de arremesso.

No período medieval existe um estado permanente de guerra, e esses cavaleiros vão constituir a base do Exército franco, porém, sem dispensar o auxílio da infantaria. Infantaria que teria importância no auxílio à cavalaria. "Torna-se, portanto, necessário, recrutar e treinar infantes, providenciar seu armamento e sua manutenção, desenvolver forjas e ferrarias que produzam armas e armaduras, sem falar na necessidade de incrementar a criação de cavalos de batalha e organizar plantações de feno e forragem, seu alimento básico." 35

Há uma mobilização de todos aqueles que possuem propriedades. Todos são obrigados a fornecer alimentação, vestuário e armas para os exércitos. Além de feno para os cavalos. Todos os homens livres do reino devem prestar serviço militar, e sua função no Exército real depende do número de mansos (árca cultivada por família) que possui.

Pelo estado permanente de guerra em que vivem esses povos, a demanda dos elementos citados acima era muito grande. Para isso, era necessária uma produção sempre ativa, desde alimentação até do próprio cavaleiro. Nasce desta maneira o que ficou conhecido como vassalagem. "Constitui-se a vassalagem no antigo costume germânico, jurar lealdade a um chefe, passando a ser seu vassalo. Tem um caráter claramente militar e compatível com uma sociedade composta de homens-livres guerreiros. Tratase, em verdade, de uma relação pessoal de dependência, de homem-a-homem,

\footnotetext{
${ }^{34}$ Idem, Ibidem. Pg. 42

${ }^{35}$ Idem, Ibidem. Pg. 44

(Rorisi ) Pamiante
} 
comportando uma verdadeira troca: a proteção de alguém mais poderoso, em virtude da prestação de algum tipo de serviço. ${ }^{, 36} \mathrm{Ou}$, como explicita Marc Bloch: "...entre as populações do imenso Império, distinguiu-se uma classe, proporcionalmente muito numerosa, de 'vassalos do senhor'- entenda-se 'do senhor Rei' (vassi dominici) - os quais, desfrutando da protecção particular do soberano e encarregados de lhe fornecerem uma grande parte das suas tropas, deviam formar ainda, através das províncias, como que malhas duma vasta rede de lealdade.",37

Um indivíduo cedia a outro um pedaço de terra como prêmio pela prestação de um serviço. Este pedaço de terra era chamado de "beneficium (benefício)","38, que futuramente será "vulgarmente chamado de feudo.,"39 A concessão do benefício implicava não só na obediência ao senhor, mas também em uma dupla função administrativo-militar. Administrativo, pois, devia gerir em nome do Rei, as diferentes regiões do Reino franco, e militar, pois, tinha a obrigação de recrutar efetivo para o Exército.

Nos primórdios da vassalagem, os escolhidos para receber a terra eram homens que formavam o mais estreito círculo de amizades com a aristocracia regional, detentora de grandes extensões de terra, que constituiria a realeza franca. Porém, devido ao estado de guerra permanente, seria necessária a construção de uma enorme rede de vassalos, não mais somente de um senhor central. "Em um período de guerra permanente, em que as necessidades de guerreiros fazem-se enormes e prementes, ocorre uma enorme difusão da vassalagem de benefício, em proveito dos vassalos do senhor e demais senhores regionais., ${ }^{, 40}$ A necessidade do cavaleiro couraçado transformou os vassalos nos responsáveis pela eficiência e pela existência do Exército.

Há dentro desse quadro político (séculos VIII e IX), um novo ordenamento social, consequiência da expansão Carolíngia e do instrumento em que tal expansão se baseou. Ou seja, o estado permanente de guerra, aliado à adoção do cavaleiro couraçado, acabam concretizando uma sociedade altamente militarizada, e também hierarquizada: o senhor que recruta mais cavaleiros sente-se mais importante que aquele que recruta menos. Nas regiões de frontcira, denominadas Marcas, estão indivíduos que, por possuírem fortificações importantes para o reino, sentem-se acima dos que não possuem. Ocorre também, ao mesmo tempo, um aumento da população de homens nãolivres, guerreiros menos abastados que não conseguiram cumprir sua função como vassalos. A população rural,por sua vez, é submetida a novos

\footnotetext{
${ }^{36}$ Idem, Ibidem. Pg. 45

${ }^{37}$ BLOCH, Marc. A Sociedade Feudal. Pg. 183

${ }^{38}$ Palavra usada "para designar as terras concedidas em troca dum serviço, e principalmente do serviço vassálico." (BLOCH, pg.190)

${ }^{39}$ BLOCH, Marc. A Sociedade Feudal. Pg. 191

${ }^{40}$ FILHO, Cyro Rezende. Guerra e Guerreiros na Idade Média. Pg. 49
} 
ordenamentos e a novas exigências. Abaixo dela, uma camada de escravos (cativos estrangeiros). "Deste modo, a extrema militarização da sociedade Carolíngia levou à sua hierarquização segundo valores estritamente bélicos, ampliou enormemente a categoria dos não-livres, e transformou o guerreiro livre em vassalo., ${ }^{41}$

A partir do século IX, o benefício passa comumente a ser chamado de feudo, e torna-se também hereditário, mais por imposição de grandes vassalos e senhores. Chegará até a ser tratado como propriedade. A rede vassálica torna-se tão vasta, que o poder central acaba por descentralizar-se. Eram tão numerosos os vassalos, que por vezes era difícil saber quem era o senhor central. "Vária vezes, vassalos recebem diferentes feudos, de diferentes senhores." ${ }^{, 42} \mathrm{O}$ feudo acaba por instituir uma intensa regionalização, assentada na prestação do serviço militar. Este fracionamento regional faz com que exista um grupo bastante heterogêneo de guerreiros, variando de região para região. Assim, "aparecem expressões designativas como: feudo de loriga, referindo-se à túnica de malha metálica, arma típica de cavaleiro; feudo de vassalo, referindose a um cavaleiro que serve com armamento limitado; feudo de sargento, referindo-se a um cavaleiro-servo, ou a uma categoria de cavaleiros auxiliares. Assim, forma-se uma pirâmide social, expressamente vinculada à categoria de serviço militar que se presta....,33

O universo feudal caminha para uma divisão sistemática de funções: o indivíduo que luta, o que reza, e o que trabalha. A escravidão é minimizada durante os séculos XI e XII, em favor da servidão, que liga o trabalhador à terra. Assim sendo, a condição de liberdade está ligada à posse de um feudo. Aqueles que não conseguem ter seu próprio feudo, colocam-se a serviço de outros como guerreiros, na esperança de obter um pedaço de terra. É dessa maneira que o guerreiro começa a ter mais espaço na sociedade; e ser guerreiro nos séculos XI e XII é ser cavaleiro.

A defesa indispensável do corpo social, fez com que os cavaleiros se elevassem socialmente. Até a primeira metade do século XI, ser cavaleiro era defender o seu senhor, a terra do seu senhor, a sua sociedade. "Durante a primeira idade feudal, o que o termo de cavaleiro queria significar era, antes de mais nada, ou uma situação de fato, ou vínculo de direito, mas puramente pessoal. Chamava-se cavaleiro porque combatia a cavalo, com o equipamento completo." ${ }^{, 44}$ Porém, foi-se criando, pelos contemporâneos dessa época, uma idéia de extrema superioridade desses cavaleiros. ${ }^{45}$

\footnotetext{
${ }^{41}$ Idem, Ibidem. Pg. 54

${ }^{42}$ Idem, Ibidem. Pg. 58

${ }^{43}$ FILHO, Cyro Rezende. Guerra e Guerreiros na Idade Média. Pg. 61

${ }^{44}$ BLOCH, Marc. A Sociedade Feudal. Pg. 348

${ }^{45}$ FILHO, Cyro Rezende, Guerra e Guerreiros na Idade Média. Pg. 79 
"A partir da segunda metade do século XI, diversos textos, que depressa vão se multiplicando, começam a mencionar que, aqui ou além, teve lugar uma cerimônia destinada, dizem eles, a "armar um cavaleiro." ${ }^{46}$ Era o Ritual da Investidura ${ }^{47}$, em que um cavaleiro mais antigo investia a um mais novo. Investir um indivíduo, era fazer com que ele ingressasse em uma "classe guerreira privilegiada..., à qual a Igreja conferiu um caráter quase religioso...",8

Fernanda Espinosa descreve em sua obra, Antologia de textos medievais, alguns momentos referentes ao armamento do cavaleiro, retirados do livro de Ramon Llull: o Libro de la Orden de Cabaleria. Descreverei estes momentos:

"1 - Primeiramente o escudeiro, antes de entrar na Ordem da Cavalaria, deve confessarse das faltas que cometeu contra Deus. [...]

2 - Para armar um cavaleiro convém destinar-se uma festa das que de preceito se celebram durante o ano. [...]

3 - Deve o escudeiro jejuar na vigília da festa. [...] E na noite antecedente ao dia em que há-de ser armado, deve ir à Igreja velar, estar em oração e contemplação e ouvir palavras de Deus e da Ordem da Cavalaria. [...]

4 - No dia da função convém que se cante missa solenemente. [...]

9 - Quando o sacerdote tenha feito o que toca ao seu ofício, convém então que o príncipe ou alto barão que quer fazer cavaleiro o escudeiro que pede cavalaria tenha em si a virtude e ordem da Cavalaria para com a graça de Deus poder dar a virtude e ordem da Cavalaria ao escudeiro que a quer receber. [...]

11 - Deve o escudeiro ajoelhar-se ante o altar e levantar a Deus os seus olhos corporais e espirituais e as suas mãos. E então o cavaleiro Ihe cingirá a espada, no que significa a castidade e a justiça. Deve dar-lhe um beijo em significação da caridade e dar-lhe uma bofetada para que se lembre do que promete, do grande cargo a que se obriga e da grande honra que recebe pela Ordem da Cavalaria.

12 - Depois de o cavaleiro espiritual e terrenal Ter cumprido o seu ofício armando o novo cavaleiro, deve este montar a cavalo e manifestar-se assim à gente, para que todos saibam que é cavaleiro e obrigado a manter e defender a honra da Cavalaria. [...]

13 - Naquele dia se deve fazer grande festim, com convites, torneios e as demais coisas correspondentes ao festim da Cavalaria. [..., $]^{, 49}$

A classe de cavaleiros torna-se, a partir deste momento (séculos XI e XII), "uma instituição..., e não apenas uma realidade nua."

Dentro de um espírito de reforma da Igreja, com início no século X, pode-se ver seu envolvimento com questões militares. A Igreja tenta definir as funções dos vassalos, ao mesmo tempo que tente fazer com que as guerras tornem-se menos sangrentas, menos violentas, mais "civilizadas".

\footnotetext{
${ }^{46}$ BLOCH, Marc. A Sociedade Feudal. Pg. 346

${ }^{47}$ ESPINOSA, Fernanda. Antologia de textos medievais. Pg. 177

${ }^{48}$ Idem, Ibidem. Pg. 175

${ }^{49}$ LLULL, Ramon. Libro de la Orden de Cabaleria. Pg. 126 a 128. IN: ESPINOSA, Fernanda. Antologia de textos medievais. Pg. 177-178

${ }^{50}$ BLOCH, Marc. A Sociedade Feudal. Pg. 348 
As primeiras tentativas da Igreja de amenizar as guerras são duas: a Paz de Deus e a Trégua de Deus. A primeira consistia em fazer com que os "funcionários da Igreja" não fossem atingidos pelas guerras. A Segunda proibia lutas durante alguns dias da semana. A Igreja tentou proibir o uso de algumas armas, como por exemplo: a besta (arma normanda, que lança dardos de metal com maior eficácia que arcos e flechas), que seria muito violenta e desonesta (os dardos perfuravam escudos de metal). Entretanto, a segunda medida foi ignorada. Enfim, a Igreja entra no mundo dos cavaleiros para tentar civilizá-los, mas vê neles poderosos aliados para combater em seu nome. Assim, adapta o ritual da investidura em um ritual quase que na sua totalidade cristão. Três ordens de cavalaria são criadas aos moldes completos da Igreja: os Hospitalários, os Templários e os Teutônicos. Tinham como objetivo combater os inimigos da cruz de Cristo. Formavam um exército permanente e mantinham-se com doações de fiéis. ${ }^{51}$

Os cavaleiros que cresciam fora do âmbito da Igreja, diferenciavam-se dos que combatiam por ela. Aqueles pilhavam para obter rendimentos extras, faziam torneios constantemente (para por em prova sua força ou para acabar com uma rixa pessoal), torneios este mal vistos pela Igreja. O cavaleiro, para ser bem quisto, deveria ter o amor do seu senhor ou Rei, um amor diferente, amor de homens. ${ }^{52}$ Era cultivado também, entre esses cavaleiros, um tipo de amor chamado "cortês": o cavaleiro conquistava o amor da dama (mulher do senhor), não para tê-la, mas para conquistar o amor do seu senhor. A Igreja era contra a cortesia entre cavaleiros, mas nada podia fazer. A cortesia, assim como todos os outros atributos dados aos cavaleiros, já faziam parte deles. Isso tudo formava o espírito cavalheiresco: honra, piedade, amor, ferocidade, superstição, luxúria, coragem, fé, devoção, vícios, assassínios, intolerância e amor ilegítimo, coexistindo em cada cavaleiro. ${ }^{53}$

\section{O"fim" da cavalaria}

O período que compreendeu os séculos XIII e XIV, foi um período de transição no que diz respeito à cavalaria. Há uma progressiva desmilitarização da sociedade; a fragm,entaçào dá lugar à homogeneidade territorial em toda a Europa ocidental; as cidades voltam a crescer, fazendo com que a população rural rume para elas. E este fato é fundamental: o feudo perde, "não só sua exclusividade em produzir a categoria de guerreiro, mas, e isto é que é importante, também sua função primeira de ser uma contrapartida pelo serviço

\footnotetext{
${ }^{51}$ FILHO, Cyro Rezende. Guerra e Guerreiros na Idade Média. Pg. 73

${ }^{52}$ DUBY, Georges. Guilherme Marechal, ou o melhor cavaleiro do mundo. Pg. 42 a 44

${ }^{53}$ PRESTAGE, Edgar. A Cavalaria Medieval. Pg. 28
} 
militar que presta." ${ }^{54} \mathrm{O}$ guerreiro passa a recebcr, pela função militar, em soldo, ou seja, em dinheiro, mesmo possuindo um feudo. Nasce, também, na segunda metade do século XIV, um novo conceito militar: a artilharia. Todo o conceito de guerra se altera, fazendo com que aquele cavaleiro, consagrado na Idade Média, desapareça, senão na sua totalidade, pelo menos fisicamente. O que fica para a posteridade são alguns conceitos, como exemplo, a noção do "ser cavalheiro". Apareceria em França, entre os séculos XV e XVI, um conceito de etiqueta baseado em alguns preceitos da Cavalaria. Mas isso é tema para outro trabalho.

\section{Bibliografia}

BLOCH, Marc. A Sociedade Feudal. Edições 70, São Paulo.

DUBY, Georges. A Sociedade Cavaleiresca. Editora Teorema, Lisboa: 1989.

DUBY, Georges. Guilherme Marechal, ou o melhor cavaleiro do mundo. Editora Gradiva, Lisboa.

ESPINOSA, Fernanda. Antologia de textos medievais. Sá da Costa Editora, Lisboa.

FILHO, Cyro Rezende. Guerra e Guerreiros na Idade Média. Editora Contexto, São Paulo: 1989.

GIORDANI, Mario C.. História de Roma. Editora Vozes Limitada, Petrópolis: 1965.

HEERS, Jacques. História Medieval. Editora da Universidade de São Paulo, SãoPaulo: 1974.

LE GOFF, Jacques. A Civilização do Ocidente Medieval. V1 1. Editora Estampa, Lisboa: 1983.

LOT, Ferdinand. O Fim do Mundo Antigo e o Princípio da Idade Média. Edições 70, São Paulo.

PRESTAGE, Edgar. A Cavalaria Medieval. Livraria Civilização-Editora.

${ }^{54}$ FILHO, Cyro Rezende. Guerra e Guerreiros na Idade Média. Pg. 83 